\title{
Project Stakeholder Management as the Integration of Stakeholder Salience, Public Participation, and Nonmarket Strategies
}

\author{
Hannah Charlotte Joos ${ }^{1} \cdot$ Dodo zu Knyphausen-Aufse $^{1}$ (D) \\ Ulrich Pidun'
}

Received: 18 August 2019 / Accepted: 25 April 2020 / Published online: 12 May 2020

(C) The Author(s) 2020

\begin{abstract}
Despite the increasingly active role of civic actors, there is often no possibility for them to participate in project planning and decision-making. This discrepancy leads to costly conflicts and even failures. Unfortunately, the literature on project stakeholder management does not have sufficient theoretical substantiation to address this issue. To fill this knowledge gap, we integrate the concepts of stakeholder salience, public participation, and nonmarket strategy, and apply them to two urban infrastructure projects in Germany. This study contributes to the literature in two dimensions. First, it offers a dynamic and conceptual model for project stakeholder management, providing explanations for different conflict intensities. Second, it advances each individual area of research. Examples include the identification and clustering of so-called nonmarket assets, an examination of the influence of nonmarket strategies on managers' perceptions of stakeholder salience, and the study of public participation in a corporate-political context, rather than a purely political one.
\end{abstract}

Keywords project stakeholder management $\cdot$ nonmarket strategy $\cdot$ nonmarket assets $\cdot$ stakeholder salience $\cdot$ public participation

Electronic supplementary material The online version of this article (https://doi.org/10.1007/ s41464-020-00092-0) contains supplementary material, which is available to authorized users.

H. C. Joos

hannah-joos@gmx.de

$\triangle$ D. zu Knyphausen-Aufseß

knyphausen@strategie.tu-berlin.de

U. Pidun

pidun.ulrich@bcg.com

1 Institute of Technology and Management, Chair of Strategic Leadership and Global Management, Technische Universität Berlin, Straße des 17. Juni 135, 10623 Berlin, Germany 
JEL Classification $\mathrm{M} 1 \cdot \mathrm{M} 14 \cdot \mathrm{L} 2 \cdot \mathrm{L} 32$

\section{Introduction}

Proponents of the Keystone XL Pipeline between Alberta, Canada, and the Gulf Coast saw it as a readily achievable and strategically compelling venture. However, despite intensive lobbying and advertising campaigns, the Obama administration stopped the project 10 years after its first proposal. While rational arguments relating to the environment, indigenous peoples, geopolitics, or conflicts of interests were already known, it was the intervention of activists, individual citizens, and public figures that increased the pressure to exigent levels (Holburn et al. 2016). For the operating company, TransCanada, this decision spelled disaster and led to a loss of USD 1.9 billion in the fourth quarter of 2015. "TransCanada has been unjustly deprived of the value of its multibillion-dollar investment by the U.S. administration's action," stated the company in a release. In 2016, the company filed a lawsuit to recover USD 15 billion in costs and damages as a result of what they considered a breach of obligations under NAFTA (CBS News 2016).

Although President Trump tried to revive the project, this example shows that civic actors are increasingly playing an active role and gaining power in major infrastructure projects, seriously affecting a company's strategy. Public and private project sponsors need to prepare need to prepare to handle such scenarios of active actor participation, especially with regard to communication and participation. The Keystone XL Pipeline project indicates that citizens are often excluded from project planning and decision-making (Flyvbjerg et al. 2003). This often leads to conflicts ranging from serious disagreements to physical violence. The higher the conflict intensity, the higher the risk of completion delays, cost overruns, reputation damages, and project cancellations - to the harm of national economies and, inter alia, the companies involved in these projects (cf., e.g., Watkins et al. 2017). To diminish this risk, finding an answer to our research question is of utmost importance: What explains conflict intensity-the expression of opposition between parties or people in their verbal and non-verbal communications (Weingart et al. 2015) - in such projects, and how can this conflict intensity be successfully handled? This article addresses this question by focusing on the dynamic interplay of three theoretical concepts - stakeholder salience, public participation, and nonmarket strategy.

Our focus on these concepts and their interplay fills the gap in the literature on project management, which does not contain sufficient theoretical substantiation to address the aforementioned issue as it is still a nascent discipline which, for a long time, focused on operational and technocratic aspects while ignoring projects' strategic framing and broader scope (e.g., Killen et al. 2012; Koskela and Howell 2002; Packendorff 1995; Söderlund 2004). Despite an increase in the number of publications on project stakeholder management (PSM), key topics, such as stakeholder influence strategies and interrelationships, remain obscure (Aaltonen et al. 2015; Achterkamp and Vos 2008; Eskerod and Vaagaasar 2014; Littau et al. 2010; Mok et al. 2015; Nguyen et al. 2018; Turkulainen et al. 2015). Teo and Loosemore (2017, p. 1444) cite Badr et al.'s (2016, p. 4) statement that "despite the recognized im- 
portance of the management of stakeholders, research projects still lack theoretical knowledge and empirical evidence from different projects and stakeholder related phenomena", as well as a similar observation by Pryke et al. (2017), to support their claim for a "relationship-based" approach to understanding the interactions of internal and external stakeholders.

We deviate from this approach not only by highlighting the conflict intensity as the final outcome to be explained, but also by introducing broadly accepted and applied theoretical concepts from strategic management into the project management literature. Our study is the first attempt to address this issue following related calls (e.g., Musawir et al. 2017; Papke-Shields and Boyer-Wright 2017; Turkulainen et al. 2015 , p. 88) while also heeding the warning that too many lenses with unclear relationships to each other can lead to loose theorizing (Okhuysen and Bonardi 2011). ${ }^{1}$

Looking at selected strategic management concepts that can be combined in a meaningful way, we take Mitchell et al.'s (1997) concept of stakeholder salience as a starting point as it explains how managers identify and prioritize stakeholders based on three relationship attributes: power, legitimacy, and urgency. Understanding this helps one realize why and when civic actors are important. Next, the concept of public participation in a political or corporate context supports managers as they steer interaction with local communities through different approaches and instruments (e.g., Brabham 2009; Kirsch et al. 1978). Finally, the inside-out view of a nonmarket strategy allows one to study political and civic players from the perspective of the firm or the project (Bach 2015) and to address concepts such as "corporate political activity" or "corporate social responsibility". These concepts emphasize the firm's ability to build up assets-for example, financial resources or reputation/credibility - that can be used in critical phases of a project. This perspective supports organizations as they work to improve performance by shaping their environment via information exchange with critical stakeholders who would otherwise be neglected (Baron 1995; Wrona and Sinzig 2018).

Still, on its own, none of these concepts explains how the mechanisms of PSM influence conflict intensity with civic actors. Our theory-building case study approach (cf. Eisenhardt 1989) aims to close this gap and obtain empirical insights to develop an advanced PSM model that integrates the three concepts. We consider two urban infrastructure projects with several distinct phases and compare how their project teams reduce or escalate conflict with local communities.

Our study contributes to academia and practice in two dimensions. First, it provides a conceptual dynamic model for PSM by highlighting how the complex interplay between stakeholder salience, public participation, and nonmarket strategy affects conflict intensity. Specifically, in a setting that requires particular attention on civic (secondary) stakeholders, our study shows the extant PSM literature falls short by focusing mainly on stakeholder analysis and interaction while neglecting the strategic component and mutual relationships, for instance. Most importantly,

\footnotetext{
1 Note that our focus lies on selected explanatory concepts and not so much on conflict intensity as the dependent variable to measure a process outcome (which in turn can be seen as a mediator to explain other outcome variables such as project risk or, eventually, project benefit (Ofer and Smyrk 2019)).
} 
nonmarket strategies and corporate managers' perception of stakeholder salience seem to be mutually dependent (Aaltonen 2011) and stakeholder salience is related to public participation. This is highly relevant, because an effective public participation framework - especially with regard to civic actors-is crucial for reducing conflicts during planning and implementation. Second, our study also contributes the individual concepts. For example, it (1) lists potential nonmarket assets and raises questions regarding the current tendency to highlight a one-directional relationship between such assets and an organization's nonmarket strategy, (2) examines the influence of nonmarket strategies on stakeholder salience, and (3) helps examine public participation in a corporate-political context. These advancements also contribute to the strategic management discipline, considering the embeddedness of companies into their social environment (Pfeffer 1987) by providing analytical tools that can help companies engaging in projects with a strong real or symbolic impact on the public domain, as is often the case nowadays. Effectively navigating civic stakeholders is essential to a strategy's success; however, it goes beyond the quest for a more active political role of corporations in the public domain, as presented in several nonmarket strategy studies (e.g., Funk and Hirschman 2017; Macher and Mayo 2015; Scherer and Palazzo 2011).

This article begins by presenting the theoretical background on PSM and the three used concepts in Sect. 2. Next, Sect. 3 introduces the research strategy and the case selection. An analysis of two cases of civic-oriented PSM follows in Sect. 4 to evaluate the applicability of the three concepts and derive the information for the conceptual PSM model. Sect. 5 recapitulates the similarities and differences between the cases, presents the final model, and provides an outlook for future research. Finally, we summarize this study's contributions and limitations in Sect. 6.

\section{Theoretical Background}

It is important to retrace the current PSM research to understand the motivation for a less linear and complex — but still theoretic-model. Similarly, a quick introduction of the three chosen concepts, stakeholder salience, public participation, and nonmarket strategies (including nonmarket assets), is necessary to justify their use in the case analysis and model.

\subsection{Project Stakeholder Management}

PSM includes all "stakeholder-related activities to support the success of a project" (Eskerod and Jepsen 2013, p. 3). It aims to enhance performance by improving the quality of decision-making and the anticipation of opportunities or threats as well as developing relationships with stakeholders to increase their support (Eskerod et al. 2015b; Kuchler 2017; Mok et al. 2015). Apart from these instrumental aspects, it also has normative motives-from the opinion that those affected by a project should be able to shape it, to the potential win-win situations due to information exchange (Derakhshan et al. 2019a; Eskerod et al. 2015b; Seltzer and Mahmoudi 2013). In contrast, PSM requires resources and bears the danger of disappointment 
and illegitimacy if expectations are not met (Derakhshan et al. 2019b; Eskerod et al. 2015a).

The literature on PSM has more than quintupled since the increased usage of the stakeholder notion after Freeman's publication in 1984 (Littau et al. 2010). Consequently, the subject became more complex, incorporating different definitions and contexts. Today, PSM explains a broad range of topics such as stakeholder analysis, stakeholder influence and stakeholder management strategies, as well as stakeholder engagement and project evaluation-that is, project success, risks, and performance (Littau et al. 2010; Nguyen et al. 2018). The literature is tightly linked to stakeholder theory, but also draws from knowledge in social and behavioral theories or marketing communication (Derakhshan et al. 2019a; Eskerod and Jepsen 2013, p. 2; Tong and Thomson 2015, p. 155). However, PSM still needs further theoretical perspectives to substantiate the often practice-oriented propositions. This criticism originates from the debate that the foundation of stakeholder theory itself is too broad and lacks integration, leading to almost content-free terms that scholars use the way they desire (e.g., Scherer and Patzer 2011; Stoney and Winstanley 2001). Consequently, Phillips et al. (2003) describe its breadth of interpretation as stakeholder theory's biggest strength as well as liability, an issue that still prevails (cf. Laplume et al. 2008; Parmar et al. 2010) despite their attempt to distill the essence and prevent misunderstandings. Hence, PSM does not only depend on an integration of theoretical perspectives but also on refinements of these concepts and theories. However, contributions to theory development are limited despite an increasingly complex understanding of stakeholders (e.g., Aaltonen et al. 2015; Achterkamp and Vos 2008; Aladpoosh et al. 2012; Killen et al. 2012; Littau et al. 2010; Söderlund 2004). This complex understanding includes different presentations of the stakeholder management process. Cleland (1986) defines four steps, Karlsen (2002) suggests six, and Suttrfield, Friday-Stroud, and Shivers-Blackwell (2006), nine. They range from defining objectives and other operational details, over stakeholder analysis to strategy development, control, and feedback. Unfortunately, the three processes are not consistent, and thus, cannot be seen as a logical extension (Mok et al. 2015). However, in all of them, the different steps need to be repeated throughout the project lifecycle to incorporate changes in the stakeholder network (Eskerod and Jepsen 2013, p. 27).

Results in PSM are often dependent on parameters such as the project type, national context, and spatial or temporal dimensions. Recently, construction megaprojects focusing on public engagement have become popular among scholars-potentially because of the adverse effect of a seemingly less powerful stakeholder group, offering a uniquely interesting and relevant research opportunity (e.g., Flyvbjerg and Turner 2017; Mok et al. 2015; Oppong et al. 2017). However, the topic would benefit from an integration of more established fields, as explained above. Therefore, this study develops a theoretical framework that dynamically combines the three selected theoretical concepts we see as appropriate in the present context, thus providing an explanation for different project conflict intensities to advance research on both project evaluation and strategy. 


\subsection{Suitable Theoretical Concepts}

As explained, several propositions for the PSM process exist (cf. Aladpoosh et al. 2012; Cleland 1986; Karlsen 2002; Kuchler 2017; Suttrfield et al. 2006). To make this knowledge more accessible to practitioners, Eskerod and Jepsen (2013) aggregate the different activities into two steps: analysis and interaction. Analysis involves the identification, assessment, and prioritization of stakeholders, and interaction is the purposeful communication design and execution to address stakeholders' needs via, for example, information, exchange, cooperation, or agreements while taking into consideration potential resource constraints. We recognize the advantages of this practice-based orientation but aim to provide theoretical substantiation to this model and study potential relationships. However, and as a major learning from the two case studies presented in this paper, we suggest that the existence and path dependency of an implicit or explicit nonmarket strategy will also have a major impact on the resulting conflict intensity of an infrastructure project, such as the one described in the introduction. The following three theoretical concepts each address one aspect of PSM activities, and, combined, provide a starting point to extend the currently limited theoretical base (cf. Sect. 2.1).

\subsubsection{Stakeholder Salience: Foundation for Stakeholder Analysis}

As mentioned, the first component in the PSM process is analysis, "an interpretation process by project managers in analyzing the project stakeholder environment" (Mok et al. 2015, p. 452). Regarding related activities, Aaltonen et al. (2015), Eskerod and Jepsen (2013) as well as Yang (2014) present practical tools for stakeholder identification (e.g., checking similar projects) and a theoretical approach for assessment and prioritization (e.g., concept of harm and help by Freeman 1984; or Savage et al. 1991). However, they also recognize that factors such as the stakeholders' legitimacy and urgency play an important role in the prioritization process. These characteristics originate from the popular concept of stakeholder salience (Mitchell et al. 1997). It assumes that stakeholders possess up to three relationship attributes that managers can perceive differently based on other influencing factors, such as a company's strategy or culture: power, which implies that a stakeholder can use or restrict resources to impose their own will; legitimacy, which means that a stakeholder's action is "desirable, proper, or appropriate within some socially constructed system" (Suchman 1995, p. 574); and urgency, which is the degree to which a stakeholder's claim calls for immediate action (Joos 2018; Mitchell et al. 1997). The combination of these attributes defines the stakeholder typology, and consequently, the need for managerial attention. This corresponds to the desired outcome of stakeholder analysis, especially since the definition of power is based on the same arguments as the concept of harm and help (cf. Mitchell et al. 1997, p. 860). Therefore, the concept of salience covers the three activities of analysis-identification, assessment, and prioritization. 


\subsubsection{Public Participation: Foundation for Stakeholder Interaction}

For the second component of the PSM process, interaction, Eskerod and Jespen (2013) suggest strategic communication design as a guiding framework. Interaction with stakeholders can be proactive or reactive and intertwine with a collaborative or power-based approach (2013, p. 47 et seqq.). However, a solid examination of a project's stakeholder interaction is only possible when focusing on one field because every field has its own industrial context with large variations regarding scale, duration, or impact and often a well-established literature (Tong and Thomson 2015, p. 155), implying that the examined group of stakeholders and the applied theoretical frame need to be carefully aligned. To study civic stakeholders, we suggest that concepts related to public participation are well suited (Seltzer and Mahmoudi 2013). Public participation is the involvement of affected persons in planning or decisionmaking (Burby 2003). In the corporate context, it reflects the democratization of business processes and is crucial for interactions with neglected but critical stakeholders (Aaltonen and Kujala 2010; Kirsch 1990; Orueta and Fainstein 2008). It helps companies activate external knowledge, manage expectations, gain legitimacy, and anticipate and control conflicts. On the other hand, it can limit their ability to act, complicate processes, or trigger critical voices (Brabham 2009; Kirsch 1990).

While Arnstein (1969) outlines a "ladder of citizen participation" in the context of federal social programs, Kirsch et al. (1978, p. 395 et seqq.) develop a theoretical view of public participation in the corporate context. It has four archetypes based on different understandings of democracy: pseudo, human resource-based, social valuebased, and authentic. As Table 1 shows, the archetypes differ in three dimensions. First is the degree of actual participation, which ranges from none to intensive. Second is the addressed stakeholder capabilities; for instance, pseudo participation is frequently disguised as participation, but it consists mainly of marketing activities and does not address any capabilities. Human resource-based participation is also limited, as it addresses solely the participants' knowledge and abilities. On the

Table 1 Overview of participation archetypes. (Based on Kirsch 1990)

\begin{tabular}{|c|c|c|c|c|}
\hline & Pseudo & Human Resource & Social Value & Authentic \\
\hline $\begin{array}{l}\text { Decision- } \\
\text { Making }\end{array}$ & $\begin{array}{l}\text { No participation in } \\
\text { decision-making }\end{array}$ & $\begin{array}{l}\text { Little participation } \\
\text { in decision-making }\end{array}$ & $\begin{array}{l}\text { Participation in } \\
\text { decision-making }\end{array}$ & $\begin{array}{l}\text { Participation in } \\
\text { decision-making }\end{array}$ \\
\hline Capabilities & $\begin{array}{l}\text { - No considera- } \\
\text { tion of values or } \\
\text { needs } \\
\text { - Rather one- } \\
\text { sided communi- } \\
\text { cation }\end{array}$ & $\begin{array}{l}\text { - Usage of partic- } \\
\text { ipants' potential } \\
\text { and resources } \\
\text { - Exclusion of } \\
\text { needs (or val- } \\
\text { ues) if possible }\end{array}$ & $\begin{array}{l}\text { - Inclusion of par- } \\
\text { ticipants' needs } \\
\text { (or values) } \\
\text { - No or little } \\
\text { focus on facts, } \\
\text { knowledge, etc }\end{array}$ & $\begin{array}{l}\text { - Inclusion of } \\
\text { participants' } \\
\text { 'hard' and 'soft' } \\
\text { inputs } \\
\text { - Consideration } \\
\text { of link between } \\
\text { needs and facts }\end{array}$ \\
\hline $\begin{array}{l}\text { Main } \\
\text { Goals }\end{array}$ & $\begin{array}{l}\text { - } \text { Simple im- } \\
\text { provement of } \\
\text { relationships } \\
\text { - Stronger iden- } \\
\text { tification with } \\
\text { taken decision }\end{array}$ & $\begin{array}{l}\text { - Activation of } \\
\text { participants' } \\
\text { knowledge and } \\
\text { abilities } \\
\text { - Mobilization } \\
\text { of consent for } \\
\text { favored decision }\end{array}$ & $\begin{array}{l}\text { - Representation } \\
\text { of e.g., societal } \\
\text { values } \\
\text { - Decision with } \\
\text { focus on needs, } \\
\text { not materiality }\end{array}$ & $\begin{array}{l}\text { - Motivation and } \\
\text { empowerment } \\
\text { of participants } \\
\text { - Authentic, ideal } \\
\text { decision with } \\
\text { high realism }\end{array}$ \\
\hline
\end{tabular}


other hand, social value-based participation ignores these but emphasizes participants' needs or values. Finally, authentic participation integrates the two previous archetypes into the most idealistic form of interaction. Third, the goals related to these participation archetypes range from a simple improvement in relationships to full empowerment of participants within the decision process.

The four archetypes were originally applied to internal stakeholders, such as employees. Employees are individuals that hold divergent values and needs but nonetheless form a community. In line with the definition by liberal thinkers who link civil society with voluntary organizations (Swyngedouw 2005), the archetypes can also provide the theoretical basis to study a project's interaction with local communities.

\subsubsection{Nonmarket Strategies: Strategic Component}

We have determined the theoretical base for the two components of the PSM process, analysis and interaction, but still lack the strategic component that makes PSM a key success factor for projects (e.g., Suttrfield et al. 2006). In the existing PSM models, strategy development follows analysis or mingles with interaction. However, we assume that companies, qua their existence, have already developed consistent behavioral patterns, or, in other words, a strategy (cf., Mintzberg 1978). This implies a mutual relationship since not only is strategy shaped by the analyses, but also influences the analyses through managerial perceptions. Indeed, two studies found that environmental strategies impact analysis by influencing managerial perception and thus increase the importance of certain stakeholders independent of their actual relevance to the company (Buysse and Verbeke 2003; Henriques and Sadorsky 1999).

As the nonmarket environment consists of, inter alia, governments and citizens, we chose the concept of nonmarket (political) strategies (Bach and Allen 2010; Baron 1995; Hillman and Hitt 1999; Hillman et al. 2004; Lawton et al. 2013). Research has demonstrated their impact: for instance, social movements can put pressure not only on individual companies but entire industries, and thus require a strategically controlled reaction scheme (Hiatt et al. 2015; Zu Knyphausen-Aufseß and Schweizer 2011). To apply such a non-market strategy scheme successfully, firms need to possess assets similar to the market sphere (Amit and Schoemaker 1993)—nonmarket assets (or resources/capabilities; c.f. Bonardi 2011; Dahan 2005; Oliver and Holzinger 2008). Nonmarket assets can take many forms, ranging from tangible assets, such as dedicated financial resources, to more intangible assets, such as reputation. For instance, a company that attributes high importance to environmental protection probably has a dedicated budget and easier access to nongovernmental organizations (NGOs) and regulative authorities due to its reputation as a fair and responsible discussion partner (e.g., Scherer and Palazzo 2007). Such assets are crucial since they may lead to a competitive advantage in the political sphere, and in the long run, also in the market sphere, as long as they are difficult to replicate for rivals (cf. Barney 1991; Bonardi and Vanden Bergh 2015) and not threatened by opposed activists (Baron 1995, p. 60).

The body of nonmarket strategy literature is growing, inter alia, along two strands: corporate political activity and corporate social responsibility (Dorobantu et al. 2017; 
Lawton and Rajwani 2015). Mellahi et al. (2016, p. 144) define corporate political activity (CPA) as "corporate attempts to manage political institutions and/or influence political actors in ways favorable to the firm." This definition introduces the company as a political actor; however, the political arena also includes citizens, as they hold not only market power (as consumers) but also nonmarket power (as voters or activists). The distinction between public and private politics reflects this. Public $C P A$ refers to attempts at influencing public institutions. Examples include lobbying, lawsuits, or business-government relations, and in extreme cases, corruption (e.g., Campos and Giovannoni 2017). Private CPA targets private agents, often in the arena of public sentiment. Examples include elections, protests, and interaction with activists (Bach 2015; Hiatt et al. 2015; Lawton et al. 2013). Both are crucial for infrastructure projects, as they demand political and civic consent. Finally, corporate social responsibility (CSR) is an "action that appears to advance some social good that allows a firm to enhance organizational performance" (Mellahi et al. 2016, p. 144). While companies often employ CSR generically, they can use targeted actions, politicized CSR, to convince stakeholders (Lock and Seele 2017). However, these actions are often criticized on account of their instrumental interpretation ("greenwashing"), which can lead to a weak position among secondary stakeholders or a separation of political and economic responsibilities (Freeman and Gilbert 1988; Jones 1995; Patzer et al. 2018; Scherer and Palazzo 2007). This includes issues of inauthentic or otherwise insufficient perceived forms of participation, as discussed in Sect. 2.2.2. Ma et al. (2017) develop a governance framework that elaborates on these issues with regard to megaprojects.

Recapitulating, the three concepts address the phenomena of critical secondary stakeholders from various angles. Stakeholder salience helps managers determine who "counts," and despite Achterkamp and Vos' (2008) preference for a role-based stakeholder model, we favor this concept, as its applicability to the project setting has been proven (e.g., Aaltonen 2011; Parent and Deephouse 2007). Next, the concept of public participation with its different archetypes provides the tools to steer interaction with affected individuals. Finally, nonmarket strategy supports an organization in positioning itself and developing an understanding of the assets it needs to achieve a competitive advantage also in the political sphere. Hence, it plays a more foundational role than the other two concepts. Together, the three concepts provide the base for a thorough analysis of the chosen cases. After the analysis of these cases, we expect to be able to integrate the most important elements into a theoretical framework.

\section{Methodology}

This study analyzes how the interplays among nonmarket strategy, stakeholder salience, and public participation explain PSM with regard to the special case of conflict with citizens. It aims to ground PSM in adequate theory without losing practical findings (e.g., Aaltonen 2011; Eskerod and Jepsen 2013). Furthermore, the novel application of the three concepts produces individual insights. 


\subsection{Research Strategy}

As the presented concepts are currently isolated, they do not provide sufficient substantiation to derive hypotheses that can be subsequently tested using a quantitative research approach. Thus, it is adequate to take an inductive research strategy, as its focus on concepts-in-use and subjectively constructed realities facilitates learning, while the close connection to the object of study ensures practicability (Flyvbjerg 2016; Gephart 2004; Siggelkow 2007). However, this study aims at transparency and discipline to enable replication and demonstrates adherence to the data (Eisenhardt et al. 2016; Eisenhardt and Graebner 2007). Hence, we adopted a multiple case study approach following the guidelines of Eisenhardt (e.g. 1989). While single interpretive case studies based on grounded theory (e.g., Gioia 2004) have become popular, a comparative case study design is more suitable for several reasons. For one, our research allows for refinement and substantiation, whereas the interpretive approach is appropriate for novel concepts. Additionally, grounded theory requires an insider perspective (e.g., working within the organization) (Langley and Abdallah 2011; Ridder 2017), and this is something we do not possess. Finally, a theory derived from comparative cases is more accurate and generalizable (Eisenhardt and Graebner 2007; Yin 1994, p. 31).

\subsection{Case Selection}

In line with our research strategy, we applied purposeful case sampling. The selection criteria included the project type and timeline, industry, experience, ownership of the project organization, and polarity with regard to project-community conflicts. The two cases selected are large-scale urban infrastructure projects in Germany. This selection accounts for the increasing number of such projects due to cities becoming prevalent social environments and pivotal terrains for new forms of social movements and governance (Alcántara et al. 2016, p. 9 et seq.; Swyngedouw 2005). Both project organizations are vital as infrastructure and employment providers, and both have conducted multiple construction projects; additionally, at their respective establishments, each organization is entirely state-owned. The long-term characteristics of this ownership, with the same persons in government and company board for many years, ensure the presence of consistent, and hence, strategic public CPA with regard to political opposition or independent national legislators. Both companies perform financially relatively well, demonstrating the successful combination of economic (market) and political (nonmarket) strategies. Their capabilities lead to the assumption of ability to pursue other forms of nonmarket strategies. The polarity between the cases arises from different conflict intensities-measured relative to previous reconstructions or expansions. Difficulties in finding access to similar constellations resulted in a limited sample; however, the analysis of distinct project phases allowed for comparisons across points in time, thus ensuring theoretical saturation (Eisenhardt 1991).

Case A, Stuttgart 21, is a project led by the railway company Deutsche Bahn (DB) to replace the terminus station with an underground through station. This project also involves the sale of the cleared area to the city of Stuttgart for urban 
development. Comparable endeavors have rarely generated greater controversy and posed more powerful repercussions (Novy and Peters 2012). Opponents argued rationally against it; however, the discussion quickly became emotional, since they felt that the economic and political elite were making decisions in the "backrooms of power" without listening to the people or discussing alternatives (Brettschneider and Schuster 2013, p. 145). A protest at the end of September 2010, in which over 100 individuals were injured, marked the climax of this conflict. The mediation process and referendum that followed only partially helped. Today, Stuttgart's society remains divided, the project timeline is regularly extended, and the project partners have sued one another over the burden of a 240\% cost increase. A recent press article reports that the project will not be finished before 2025 and that DB has to mobilize about EUR 3.3 billion until 2023 (Wille 2019) — a disaster comparable to the Keystone XL-Pipeline project referred to in the introduction of this article.

Case B, Runway North-West/T3, relates to the Frankfurt airport's construction of a new runway and a third terminal. While the terminal is on the ground of a former airbase, the runway caused deforestation, prompted the relocation of a chemical plant, and increased air traffic. These changes led to various citizen initiatives, each raising its own concerns. After violent protests that caused two deaths during an expansion in the 1970s and 1980s, both the responsible company Fraport and political decision-makers were aware of the importance of pursuing an open dialogue in the early days. This approach, especially with regards to aircraft noise, today serves as an international role model of engagement (Fraport 2014, p. 5). Table 2 provides details of both cases.

Following careful analysis and expert discussions, both cases were divided into phases, with each phase characterized by a strategic orientation, a distinctive project-community relationship, and key events (cf. Figure A1, online appendix). Stuttgart 21 has four phases: 1994-1997, planning; 1997-2010, conflict climax; 2010-2013, rapprochement; and 2013 onwards, implementation. Runway NorthWest/T3 has three phases: 1997-2000, ramp-up; 2000-2008, planning; and 2008 onwards, implementation.

\subsection{Data Sources and Analysis}

Primary data were drawn from 14 open-ended, one-to-one interviews conducted by the first author. Each interview started with a discussion of the key terms and project phases, followed by questions and possibility of comment. Interviews were conducted with company employees, politicians, and community activists chosen based on criteria such as maximum affiliation with the project in terms of duration and responsibility, regular contact points with the other parties, and maximum degree of neutrality (more details in Table A1, online appendix). All informants were directly related to the projects and had invested a significant amount of their time in the planning and implementation phases. The interviews lasted for an average duration of $57 \mathrm{~min}$ and were mostly conducted face-to-face to ensure local groundedness. This, taken together with interviewee diversity and anonymity, helped limit information bias. The 350-plus pages of transcriptions were member-checked. Secondary data were grouped into two categories. First, data were sourced from publicly 
Table 2 Case overview including key parties and arguments

\begin{tabular}{|c|c|c|}
\hline & A Stuttgart 21 & B Runway North-West/T3 \\
\hline $\begin{array}{l}\text { Project De- } \\
\text { scription }\end{array}$ & $\begin{array}{l}\text { Rail project incl. replacement of the ter- } \\
\text { minus station by an underground through } \\
\text { station and urban development on cleared } \\
\text { area in the city center ( } 100 \text { ha) }\end{array}$ & $\begin{array}{l}\text { Construction of a fourth runway } \\
\text { on a formerly protected forest area } \\
\text { ( } 220 \mathrm{ha}) \text {, including a third terminal } \\
\text { and expansion of cargo area }\end{array}$ \\
\hline $\begin{array}{l}\text { Conflict In- } \\
\text { tensity }\end{array}$ & $\begin{array}{l}\text { High (unique case for DB AG and Germany } \\
\text { in general) }\end{array}$ & $\begin{array}{l}\text { Low (e.g., compared to previous } \\
\text { project Runway } 18 \text { West) }\end{array}$ \\
\hline $\begin{array}{l}\text { Timeline } \\
\text { (status quo) }\end{array}$ & 1994-2025 & $1997-2023$ \\
\hline $\begin{array}{l}\text { Volume (sta- } \\
\text { tus quo) }\end{array}$ & $€ 8.2 \mathrm{~B}$ & $€ 4.0 \mathrm{~B}$ \\
\hline \multirow[t]{3}{*}{ Key Parties } & Business: Deutsche Bahn AG & Business: Fraport AG \\
\hline & $\begin{array}{l}\text { Politics: federal state (Germany), state } \\
\text { (Baden-Württemberg), region (VRS), city } \\
\text { (Stuttgart) }\end{array}$ & $\begin{array}{l}\text { Politics: state (Hessen), city (Frank- } \\
\text { furt) }\end{array}$ \\
\hline & $\begin{array}{l}\text { Communities: several citizens' initiatives } \\
\text { (e.g., Leben in Stuttgart—-kein Stuttgart } 21 \text {, } \\
\text { Parkschützer) }\end{array}$ & $\begin{array}{l}\text { Communities: several citizens' initia- } \\
\text { tives (e.g.,from Kelsterbach, Sachsen- } \\
\text { hausen, or Flörsheim-Hochheim) }\end{array}$ \\
\hline $\begin{array}{l}\text { Founding } \\
\text { Date }\end{array}$ & $1924^{\mathrm{a}}$ (listed since 1994, no IPO) & 1947 (IPO in 2001) \\
\hline $\begin{array}{l}\text { Main Indus- } \\
\text { tries }\end{array}$ & $\begin{array}{l}\text { Transport, infrastructure provision, railway } \\
\text { operation }\end{array}$ & $\begin{array}{l}\text { Transport, airport provision/ } \\
\text { operation, ground handling }\end{array}$ \\
\hline $\begin{array}{l}\text { Company } \\
\text { share .owned } \\
\text { by public } \\
\text { authorities }\end{array}$ & $100 \%$ & $51 \%(100 \%$ until 2001) \\
\hline $\begin{array}{l}\text { Revenues } \\
(2016)\end{array}$ & $€ 40.6 \mathrm{~B}$ & $€ 2.6 \mathrm{~B}$ \\
\hline $\begin{array}{l}\text { Employees } \\
(2016)\end{array}$ & $\sim 306,000$ & $\sim 20,000$ \\
\hline \multirow[t]{3}{*}{$\begin{array}{l}\text { Supporters' } \\
\text { Key } \\
\text { arguments }\end{array}$} & $\begin{array}{l}\text { Economic prosperity (rebirth of the city } \\
\text { center, reputation of the region, creation of } \\
\sim 24 \mathrm{k} \text { jobs) }\end{array}$ & $\begin{array}{l}\text { Economic prosperity (busi- } \\
\text { ness, tourism, creation of new } \\
\text { jobs-largest employer of the region) }\end{array}$ \\
\hline & $\begin{array}{l}\text { Efficiency (faster transport links, less road } \\
\text { traffic) }\end{array}$ & $\begin{array}{l}\text { Increasing passengers and air traffic } \\
\text { (capacity bottleneck) }\end{array}$ \\
\hline & $\begin{array}{l}\text { Limited costs (self-financing due to land } \\
\text { sale) }\end{array}$ & $\begin{array}{l}\text { Better quality of service (boarding, } \\
\text { less handling on apron) }\end{array}$ \\
\hline \multirow[t]{4}{*}{$\begin{array}{l}\text { Opponents' } \\
\text { Key } \\
\text { arguments }\end{array}$} & $\begin{array}{l}\text { Ecological and safety issues (endangered } \\
\text { species, old trees, difficult geological ter- } \\
\text { rain) }\end{array}$ & $\begin{array}{l}\text { Health risks and ecological issues } \\
\text { (increase of noise and air pollution, } \\
\text { deforestation) }\end{array}$ \\
\hline & $\begin{array}{l}\text { Assumptions (higher costs, limited practi- } \\
\text { cality) }\end{array}$ & $\begin{array}{l}\text { Assumptions (ignorance of studies, } \\
\text { demand too optimistic) }\end{array}$ \\
\hline & $\begin{array}{l}\text { Process issues (little transparency, no alter- } \\
\text { native) }\end{array}$ & Process issues (little transparency) \\
\hline & $\begin{array}{l}\text { Social concerns (selectivity, no historical } \\
\text { preservation) }\end{array}$ & - \\
\hline
\end{tabular}


Table 2 (Continued)

\begin{tabular}{lll}
\hline Aingularities & $\begin{array}{l}\text { A Stuttgart 21 } \\
\text { Volatile opinions of DB AG and German } \\
\text { State allowed citizens to form resistance } \\
\text { during longer than usual period }\end{array}$ & $\begin{array}{l}\text { Opposite opinions within one party } \\
\text { (e.g., city mayor was contra vs. sup- } \\
\text { porting official role of city of Frank- } \\
\text { furt) }\end{array}$ \\
& $\begin{array}{l}\text { Civil society rather positive at project start, } \\
\text { opinions changed over time (see previous } \\
\text { point) }\end{array}$ & - \\
& $\begin{array}{l}\text { Unusual composition of protestors (conser- } \\
\text { vative middle and upper class, rather older } \\
\text { generations) }\end{array}$ & - \\
\hline
\end{tabular}

${ }^{\text {a }}$ Created from the regional railways of the individual states of the German Empire and divided from 1945 to 1993 (East and West Germany)

accessible sources, such as 150-plus newspaper and magazine articles, press releases, websites, footage from meetings, and academic publications (Brettschneider and Schuster 2013; Peters and Novy 2012; Schmidt-Thomé and Mäntysalo 2014). Second, data came from less readily available sources, including documents from corporate intranets (e.g., development plans, cooperation principles) and memos of informal conversations with other employees while having lunch, for instance. Secondary data were not used for quotes, but it ensured an efficient focus and accurate interview interpretation, thus minimizing the risk of deriving less-than-insightful primary data. The triangulation also supported the evaluation of, for example, salience attributes. Overall, the richness of the secondary data helped ensure the results were sufficiently robust, despite the relatively few interviews conducted.

The data collection and analytical processes, including the within-case narratives and cross-case analysis, overlapped to ease theory refinement and improve the outcomes. It followed Miles and Huberman's (1994, p. 12 et seq.) three-step iterative process comprising data reduction, data display, and conclusion drawing or verification. Tabular displays supported analysis, and within this process, we used the narrative and temporal bracketing strategies of sense-making (e.g., Langley 1999). Each data point acted as a check against the others to ensure that no statement was true of only one source (Kanter 1977). We coded on descriptive, interpretative, and inferential levels with ATLAS.ti.

\section{Case Analysis}

The two polar cases, Stuttgart 21 and Runway North-West/T3, support the evaluation of the applicability of the chosen concepts and the conception of the model. Such an iterative process ensures a theory and reality match (Dubois and Gadde 2002). This section is organized according to the relationships between the different concepts and the outcome of the projects. The first subsection discusses the one- or two-directional relationships between nonmarket strategies and their underlying assets, based on the assumption that only such a reinforcing structure can provide the openness and capabilities to deal with demanding secondary stakeholders. The second subsection 
then shows how nonmarket strategies influence stakeholder analysis, or the salience attributed to local communities, highlighting the importance of adequate stakeholder perception through the different phases of a project. The third subsection elaborates how perceived stakeholder salience determines the participation framework that integrates the stakeholders. The last subsection links the PSM activities, namely, the participation of stakeholders with the outcome-that is, the intensity of the conflict between the focal company and the local communities-as well as the economic risk this may imply. Each of the following subsections introduces the detailed research approach, presents the findings from the two cases, and strives to substantiate them with the three theoretical concepts of nonmarket strategy and assets, stakeholder salience, and public participation. Sect. 5 integrates all these elements into an overarching framework.

\subsection{Nonmarket Assets and Strategies}

Despite a growing literature on nonmarket strategy (cf. Sect. 2.2.3), very few studies have examined what defines the underlying nonmarket assets and their relationship to the respective strategy (cf. Bonardi 2011; Bonardi and Vanden Bergh 2015; Oliver and Holzinger 2008). However, these matters are crucial in determining the influence of an organization's strategic focus on its PSM. Hence, we determined the soft and hard nonmarket assets that managers need to undertake stakeholder analysis and interaction. We identified the soft nonmarket assets as follows: (a) awareness regarding the environment, (b) ability to learn and experience, (c) relationships with local communities, (d) flexibility, (e) preparedness, and (f) communication. Any of these can be possessed by an individual; however, all need to be nurtured by the project organization (Jones et al. 2007). Hard nonmarket assets include the (g) organizational structure, (h) governance or lines of responsibility, and (i) resources, all generally driven by the parent company. We evaluated the assets through the lens of local communities and matched them with the prevailing strategies in the project organizations (private CPA, public CPA, and politicized CSR, such as real estate programs or hotel stays for residents). We found that private CPA and politicized CSR are positively linked to the community-related nonmarket assets. We assume that this relationship is self-reinforcing, in line with the traditional strategy literature but in contrast to the numerous nonmarket strategy publications that focus only on the one-directional influence of organizational characteristics (cf. Wrona and Sinzig 2018). On the contrary, public CPA, while visible in decisions and actions, does not affect the chosen nonmarket assets as it does not promote focus on private agents. Table A2 in the online appendix summarizes the results and presents illustrative quotes; selected examples follow.

A good example of the relationship between nonmarket strategies and soft nonmarket assets is the awareness regarding a project's environment. At the beginning of their respective projects, DB pursued public CPA, whereas Fraport additionally incorporated private CPA. DB focused on the governing elite, which led to insensitivity regarding civil stakeholders and emerging protests. As one interviewee said, "At that time, nobody thought that there could be (...) a different constellation. Therefore, the focus was not on politicians, only on those in charge." Additionally, "DB 
did not see itself as an urban planner, assuming that it builds underground and others can discuss what to develop above." The awareness was higher in Frankfurt, with decision-makers having "huge respect for the discussions." Further, the government of the federal state changed regularly (in 1991, 1999, 2003, etc.), leading not only to public, but also private CPA, as local communities were seen as voters. The nature of the stakeholder relationship with citizens is similar. In Stuttgart, interactions were not initially seen as important; indeed, opinions were temporarily so strong that "people forgot that their counterparts were humans," and this caused "citizens to become suspicious and feel the need to intervene." Things did improve, but the divide is still almost tangible, as continued weekly demonstrations and letters to newspapers show. In contrast, the more private-oriented Fraport "accepted that there were always groups that were disappointed," but they nonetheless recognized that "it was important to continue the discussion."

The relationship with nonmarket strategies also exists for hard nonmarket assets such as corporate structure. For 19 years, Stuttgart 21 was steered by the corporate headquarters. In 2013, the shift towards private-oriented nonmarket strategies and the concurrent creation of a project company improved flexibility and exchange. As one employee remembered, “the project company's managers were committed to talking personally with all representatives-not only to the institutionalized or democratically legitimatized groups, but also to the affected citizens." In contrast, Fraport exhibited private CPA by instantly creating a specialist communication department. Today, it is ramping down these structures while still "optimizing the management of complaints" via digitalization. Closely interlinked with corporate structure is governance. In its first phases, Stuttgart 21 did not assign clear responsibilities, resulting in "project partners communicating separately out of their resorts." Owing to a culture of decision-making avoidance and limited support from the ultimate owner (i.e., the German state), "citizens got the impression that the project team did not know what they were doing." The processes and structures of the new project company brought significant improvement in these matters. Interestingly, development at Fraport rolled out in a reverse order, with clear responsibility sharing in the initial phases and, as an informant explained, "...eroding responsibilities in 2017."

How can we connect these observed interlinkages between nonmarket assets and nonmarket strategies to the literature? The early market strategy literature provides explanations regarding the relationship between at least one specific organizational characteristic, structure, and strategy. Chandler (1962, p. 14) defines structure as "lines of authority and communication (...), and, second, the information and data that flow through these lines." Over time, scholars extended this definition with managerial characteristics, the formal distribution of roles, and corporate culture, for instance (e.g., Burgelman 1983; Hall and Saias 1980; Venkatraman and Camillus 1984). All agree that strategy and structure are linked independently of reconstructionism (strategy shapes structure) or structuralism (strategy follows structure). While these publications focus on the market side, we assume their validity for nonmarket strategies, as both are complementary: nonmarket assets, such as the ability to learn, are capabilities that serve firms when executing market strategies too. The case findings also confirm that the relationship is not one-directional as in 
most nonmarket publications that describe organizational characteristics exclusively as antecedents (e.g., Lamberg et al. 2004; Schuler 1996). Nonmarket strategy and nonmarket assets reinforce each other, even if the strategy is not explicitly stated (cf. relationship 1 in Fig. 2, Sect. 5).

\subsection{Nonmarket Strategies and Stakeholder Salience}

Some studies examine the impact of nonmarket strategies on managers' perception of stakeholder salience, and thus, on their analysis, for primary stakeholders (Buysse and Verbeke 2003; Henriques and Sadorsky 1999). The following offers greater clarity regarding secondary stakeholders and analyzes if the relationship is also inverse-in other words, whether stakeholder salience also affects nonmarket strategies. For every project phase, we gathered data on the salience attributes of the local communities. Based on the strength of the attributes, we determined actual salience and compared it to perceived salience. Actual salience reflects the opinion of the whole network (i.e., business, politics, citizens, media), while perceived salience only reflects the view of the decision-making project members. While reality and perception are often interchangeable on an individual level, the examined cases reveal situations with such immense deviations that a distinction is necessary. These deviations were set against the prevailing nonmarket strategy (cf. Sect. 4.1). The results revealed that the absence (existence) of a private-oriented nonmarket strategy decreases (increases) the salience attributed to local communities, especially prior to implementation. Hence, nonmarket strategies influence stakeholder analysis, and depending on their orientation, intensify or weaken the PSM. Regarding the inverse relationship, we found that actual salience does not influence strategic choices, whereas perceived salience does. Table A3 in the online appendix provides an overview of our data and related analysis.

The analysis demonstrates that in the first two project phases, Stuttgart 21 perceived the salience of local communities to be too low, whereas Runway NorthWest/T3 did the opposite. This divergence can be explained by their different strategic orientations. As one interviewee stated, for Stuttgart 21, "citizens were clearly not a relevant stakeholder group." This corresponds with the observation that the project did not have a private-oriented nonmarket strategy and that the public nonmarket strategy focused on the governing elite. This resulted in the local communities being ignored, despite signs of their rising legitimacy and power through legal protests and requests for referendums. One informant described the situation after a large demonstration: "They [project team] reacted helplessly. I heard questions like 'Who are those troublemakers?' However, they did not take the protesters seriously." Seven months later, in September 2010, the conflict culminated in an unprecedented violent demonstration, known as "Black Thursday," in which many were injured. Subsequent fact-checking mediation calmed the situation. Nevertheless, only the state elections and the resulting referendum about project stoppage emphasized private-oriented CPA, leading to realistic perceptions of the communities' salience. This strategic adjustment was noticeable with the creation of the project company, and not before, when high actual salience levels would have recommended it. Hence, actual salience did not drive nonmarket strategy. 
On the other hand, from the beginning, Fraport focused on local communities, as "in the first phase the focus was on avoiding societal tensions." Furthermore, Fraport's credo of "the license to grow, to operate (...) -we can only pursue or expand our business if our business model is accepted by the society" links the market to the nonmarket environment. Accordingly, civic actors had high salience. During implementation, the actual and perceived levels of salience converged, as Fraport managed to preclude severe conflicts by offering participation and making compromises, such as a ban on nighttime flights.

Given these observations, how can nonmarket strategies influence the salience attributed to local communities? Research shows that a manager's perception of a stakeholder is critical to the perceived importance of that stakeholder (Buysse and Verbeke 2003; Henriques and Sadorsky 1999). Our case studies complement these findings. First, the results regarding secondary stakeholders can be explained by the fact that key stakeholders vary substantially, depending on the strategy and the institutional context (Buysse and Verbeke 2003). This is relevant, since a private-oriented nonmarket strategy that focuses on voters naturally assigns them importance, independent of any salience attributes. Second, we expand upon the environmental strategies with a broader view of nonmarket strategies. However, surprisingly, we found a misalignment between the perceived and the actual salience. This shows that the decision-makers are detached from the network and perceive reality from a different lens, either reinforcing or weakening facts based on the dominant strategy. Previous PSM models do not make such an ontological distinction, as they assume that at an individual level, perception and reality are congruent. However, this ignores the possibility of actually converging them because of a better awareness of the environment, for instance. Finally, the observed positive or negative reinforcements occur mainly during the initial phases, as the implementation increases awareness of the project's consequences. Therefore, we confirm that nonmarket strategies influence the perceived salience attributed to local communities, especially before project realization (cf. relationship 2 in Fig. 2, Sect. 5).

\subsection{Stakeholder Salience and Public Participation}

Although public participation research in the political sphere is vibrant (e.g., Herian et al. 2012; Jun and Bryer 2017), academic publications on the corporate sphere are few (e.g., De Schepper et al. 2014). This subsection examines whether public participation in a corporate-political context is driven by analysis, as defined by Eskerod and Jepsen (2013) (see above), or directly by a nonmarket strategy. We studied the use of the four participation archetypes (cf. Table 1). The analysis included only voluntary offers and disregarded legally required participation, such as planning approval procedures. One exception is Stuttgart's referendum, in which the rejection of previous requests indicated the power of the project team. We compared the identified archetypes with the nonmarket strategies and the salience levels presented in the previous subsection. The results indicate that the perceived salience level influences participation, especially before implementation. These findings confirm that stakeholder analysis influences interaction, and vice versa. Table A4 in the online appendix provides interview quotes and the results of our analysis. 
During the initial phases, the Stuttgart 21 project team offered only pseudo participation, whereas that of Runway North-West/T3 used human resource-based and authentic tools. While Frankfurt's project maintained its offering in subsequent years, Stuttgart 21 had to improve it, and even included a social value-based tool. One politician remembered, "DB had a passive role in the process, saying that 'the topic of public participation is your job.'” This neglect of civil stakeholders, as mentioned, contrasted strongly with their importance. As private-oriented nonmarket strategies did not exist, it is likely that the perceived salience influenced the chosen stakeholder interaction. This changed when actual and perceived salience converged, leading to human resource-based, and with the referendum, social value-based participation. One employee stated that today, "there are regular meetings [with residents] with open discussions." Owing to the ongoing implementation, the local communities can no longer participate in decision-making, but they can at least improve their situation. However, the data are not sufficiently rich to determine whether nonmarket strategies also have a direct effect, as discussed in the previous subsection.

The Runway North-West/T3 case demonstrates that early mediation and expert forums stemmed from perceived high salience and strategic focus. The politicians in the supervisory board drove authentic and human resource-based participation, as one employee remembered, "The state chancellery had the lead and started this process"; moreover, he remarked, "You cannot wait until the citizens do something. We discussed this with the politicians. (...) Citizens vote and politicians look at their election results. So we kept contact with both." Therefore, the perceived power and legitimacy of citizens facilitated participation. One employee stated, "The citizens are the sovereigns and decide at the end of the day." Another informant said, "The supervisory board did not play a key role. Crucial for the question 'Should we proceed in detailing the extension plans?' was only the mediation result." Ultimately, this process reinforced itself: "The participation made us learn that it is not sufficient to enforce power, since power is not in our possession but only granted to us."

Following the findings of the case analysis, we ask, how are stakeholder interaction and analysis interlinked? Existing PSM models (cf. Sect. 2.1) propose the use of analytical output in planning how to relate to stakeholders. However, both are intertwined, as stakeholder interaction reveals information that influences future analyses (Eskerod and Jepsen 2013, p. 27). As mentioned in the previous subsection, the existing models do not distinguish between perceived and actual salience. Therefore, we turn to Mitchell et al. (1997) who reveal the cognitive limitations of stakeholder analysis because managerial reality is subjective. This issue is difficult to mitigate but emphasizes the importance of a regular exchange with stakeholders. Furthermore, the cases indicate that the difference between perceived and actual salience becomes less significant during the implementation. Hence, we conclude that an increase in the perceived salience attributed to the local communities and improved offers of public participation reinforce each other, especially during the first project phases (cf. relationship 3 in Fig. 2, Sect. 5). 


\subsection{Public Participation and Project Conflict Intensity}

The participation archetypes originally apply to internal communities (cf. Sect. 2.2); however, as social activism and citizens' expectations increase, it is crucial to evaluate their impact on the process (decision-making) and result promotion (implementation) in an external context. Therefore, we analyzed the timing of the participation instruments as well as their outcome on indecisive/moderate and opponent citizens. The aim is to better link PSM activities with the actual outcome-conflict intensity. Fig. 1 presents the findings (cf. Table A5, online appendix, for additional quotes). Although these results are not comprehensive, they do suggest that a combination of knowledge exchange and consideration of needs will minimize conflict potential, whereas providing transparency cannot suffice. This adds to our statements on the convergence between perception and reality. Thus, knowledge exchange and consideration of needs help promote both decision-making and implementation, so long as the project's ability to act is secured. The choice of instruments, timing, expectation management, and common understanding of issues are all fundamental to preventing adverse side effects.

As presented, the projects took different approaches. Consequently, public participation first complicated PSM for Stuttgart 21 but eased it for Runway NorthWest/T3. Stuttgart 21 started passively, by offering mostly public events similar to press conferences, without room for discussion. The city initiated urban development workshops, but they were hosted too early and were "not related to the actual infrastructure project" (interview). Citizens interested in the train station had no arena for expressing their needs, providing input, or understanding the decisions. They felt patronized and considered the offerings to be hypocritical, leading to more opposition. One informant remembered, "We had the support and euphoria (...) but then, we lost a lot." As the decision-makers became aware of the lost ground, they offered an unprecedented nine-day, expert-level fact-checking session that was publicly broadcasted. While "it calmed the situation," both its focus on facts and its late timing failed to convince the citizens, who summarily used the following state elections to punish the government as a project member. During the same phase, the new government decided to conduct a referendum on a construction stop. This social value-based tool put the project's ability to act at high risk. Today, the team promotes transparency, advertises the project, and talks personally to affected residents. However, the number of opponents is still high, because of the emotions involved and the enormous cost increase.

Runway North-West/T3 experienced a similar initial situation but used an integrated approach featuring several participation archetypes. Over time, the focus shifted towards indecisive or moderate citizens, as from a societal standpoint, the few extreme opponents had less legitimacy, given their refusal to participate. The project team avoided many conflicts and prepared an easier implementation by offering early participation: "We opted as quickly as possible for participation-independently of formal [legally required] procedures, which are very strict and do not give the possibility to discuss and reflect." Moreover, sound expectation management minimized negative feelings. Fraport made it clear that they had a construction permit but were nonetheless willing to compromise. One citizen representative stated, "We were still 
successful as we made a huge step forward with the night flight ban and other restrictions (...). There are opponents, but I think without those compromises resistance would be much higher." Even today, the airport offers forums of exchange and neutral channels for complaints, with one interviewee remarking, "The dialogue needs to continue," because "Citizens who are suffering from this airport need to know that they are not alone."

How can these contrary observations be explained? Participation is an arena of conflict regulation: it can trigger more frequent but less intense conflicts, as they are linked to specific issues and are not suppressed. Depending on the instrument used, participation fosters up to two capabilities, exchange of knowledge and consideration of needs (cf. Sect. 2.2). Information provision assists in adapting expectations and improving mutual understanding and solution finding. A closer relationship through participation also strengthens the appreciation of others' needs, which is a driver for compromises. However, pseudo participation does not improve either of the two, as it focuses on improving relationships through transparency or marketing. While this can enhance identification with a decision, it does not regulate conflict (Kirsch 1990, p. 161 et seqq.). Therefore, public participation in a corporate-political context must not be limited to these instruments, as only a combination featuring knowledge exchange and considerations of needs will mitigate conflict potential.

As these two capabilities require resources, a trade-off with the project's ability to act seems unavoidable. Along with responsiveness and learning aptitudes, the ability to act is crucial for organizations' outcome (progress) (Kirsch 1997, p. 8 et seq.). Surprisingly, Runway North-West/T3 showed that it is possible to overcome this trade-off. By framing participation in dimensions such as group size, roles of participants, or duration, the project team ensured their ability to act. Simultaneously, the increasing number of supporters-because of the possibilities afforded by participation-added backing. Scholars found similar evidence in the case of workplace codetermination, where an increase in individual-level satisfaction fosters cooperative behavior (Kirsch et al. 1984). Nevertheless, process promotion (decisionmaking) can be difficult if participation leads to delays or ambiguous compromises (Kirsch 1990, p. 165). If these issues are not addressed, they manifest during the result promotion (implementation) via increased costs or attempts at adjustment, as the Stuttgart 21 case shows. Therefore, public participation only improves decisionmaking and implementation if the instruments do not limit the managers' ability to act.

Through the cases, we identified four additional key risks. First is the choice of instruments. At the project's outset, Stuttgart's citizens were offered only top-down events. Given their size and lack of goal setting, they were difficult to control and not fact-based. Instead, the discussions mostly attracted opponents, which in turn created a heated atmosphere and intimidated neutral citizens. A second risk is incorrect timing. Runway North-West/T3 started even before detailing the plans. Contrarily, Stuttgart 21 only offered real participation when conflicts were intense and sunk costs were high. This increased pressure and emotions, leading to dangerous veto positions and the risk of expensive project failures. The third risk is poor expectation management. Citizens attending the Stuttgart 21 events expected to discuss if and how the project would be realized; instead, they were confronted with already-made 


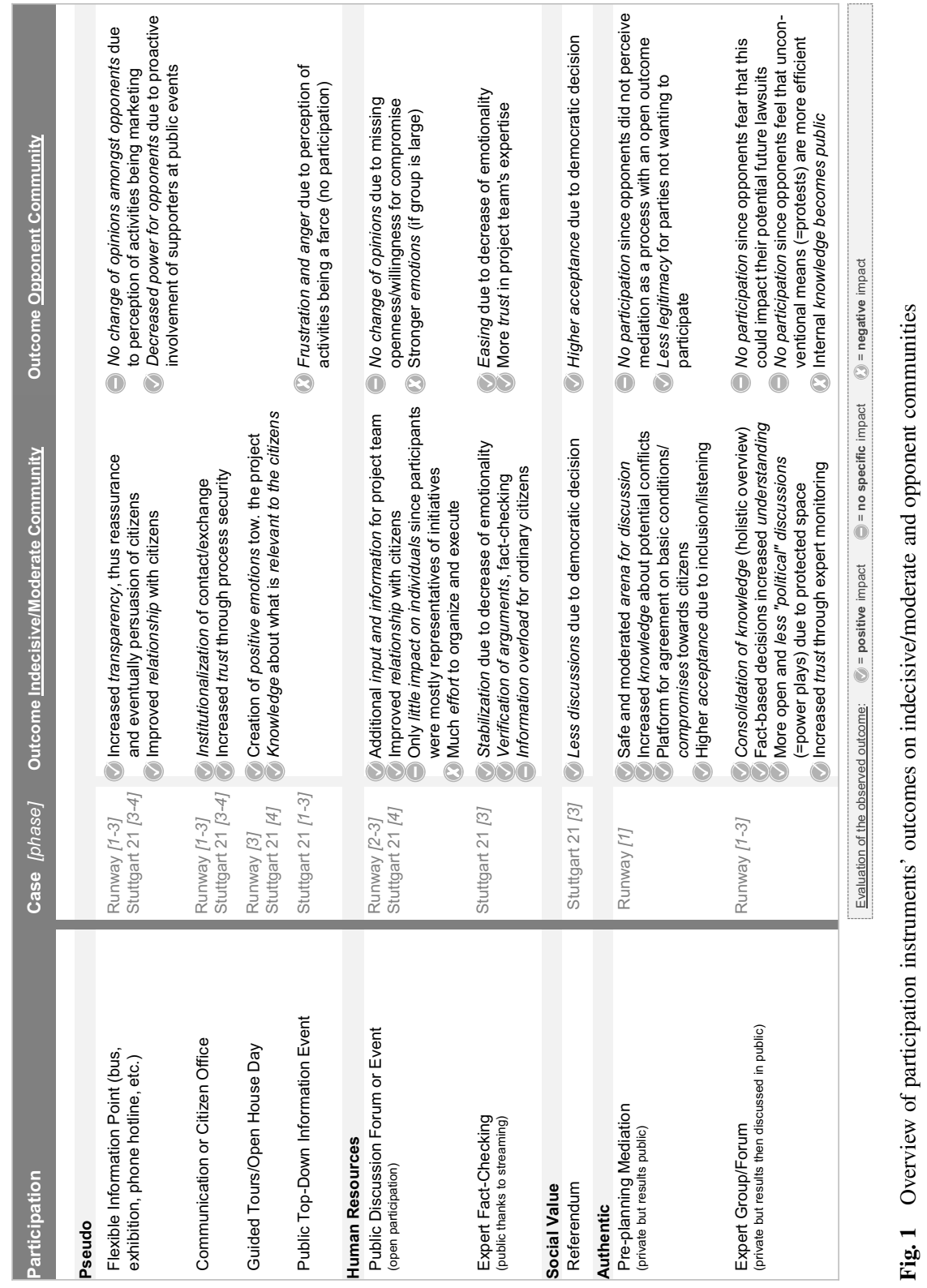




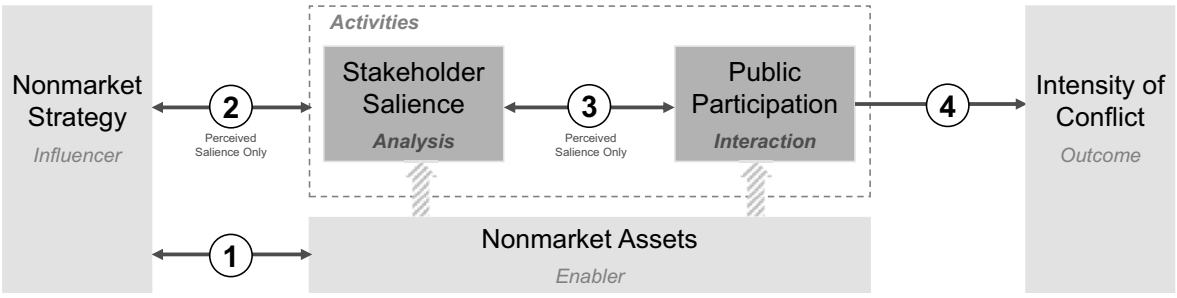

Fig. 2 Project stakeholder management framework including subsections' focus and identified relations

decisions. In contrast, Fraport communicated that while it had secured government support, it was willing to discuss alternatives and make compromises. This helped citizens understand that there would be changes, but that they could shape them by participating. The last risk is the formulation of issues to be solved. The Stuttgart 21 project team elaborated on alternatives in an isolated manner, made decisions, and then went public. Using this chain of action is dangerous, as understandings of the problem, and thus, selection criteria, can be different. However, if those risks are addressed, say, through thorough and strategic stakeholder management, a positive impact on conflict intensity with a project's local communities is always possible (cf. relationship 4 in Fig. 2, Sect. 5).

\section{Towards an Integrative Framework for PSM}

What explains the conflict intensity in major infrastructure projects and how can it be successfully handled? We aim to answer this research question by continuing to explore the two case studies, Stuttgart 21 and Runway North-West/T3, discussed in the previous sections. Apart from the comparable setup, there are several similarities between the two cases, as summarized in Table 3. In both examples, managers started with a perception of the communities' salience, which was not congruent with a neutral view of the stakeholder network. However, as the projects were implemented and consequences became clearer, perceived and actual salience converged. This is interlinked with the fact that in the end, both projects showed integrated CPA and CSR strategies with corresponding approaches to public participation, having a positive —or diminishing —impact on conflict intensity. Still, the projects differed extremely in their internal dynamics. The key driver for these differences is the strategic orientation. Focusing on both public and private stakeholders ensures adequate attention, but also requires supporting mechanisms, such as clear responsibilities, budget, and openness to learn from own and others' experiences. Consequently, it promotes interaction forms that aim to find acceptable compromises without putting the project at higher risk. These interaction forms focus on the promotion of the decision-making process instead of the promotion of the results or implementation (cf. Kirsch 1990). The focus is the opposite for a strategy ignoring civic stakeholders (e.g., by public CPA). To do so seems easier at the beginning, but unresolved conflicts can quickly escalate and prevent objective discussions. Hence, it is favorable to invest in stakeholder engagement during the first phases of the project, even for 
Table 3 Comparison of Stuttgart 21 and Runway North-West/T3 case studies along the PSM components

\begin{tabular}{|c|c|c|}
\hline $\begin{array}{l}\text { PSM Com- } \\
\text { ponent }\end{array}$ & Stuttgart 21 & Runway North-West/T3 \\
\hline $\begin{array}{l}\text { Nonmarket } \\
\text { Strategies } \\
\text { (Influence) }\end{array}$ & $\begin{array}{l}\text { First pure focus on the ruling party (lim- } \\
\text { ited public CPA), then broader but reac- } \\
\text { tive and instrumental strategy that also } \\
\text { addresses citizens and other political par- } \\
\text { ties (public/private CPA, politicized CSR) }\end{array}$ & $\begin{array}{l}\text { From the beginning on pro-active inte- } \\
\text { gration of public and private-oriented } \\
\text { strategies (public/private CPA), during } \\
\text { implementation also instrumental use of, } \\
\text { e.g., subsidies and real estate programs } \\
\text { (politicized CSR) }\end{array}$ \\
\hline $\begin{array}{l}\text { Stakeholder } \\
\text { Salience } \\
\text { (Analysis) }\end{array}$ & $\begin{array}{l}\text { First, perceived salience of local com- } \\
\text { munities lower than actual importance; } \\
\text { thereof resulting conflicts lead to a con- } \\
\text { vergence of perception and reality }\end{array}$ & $\begin{array}{l}\text { First, perceived salience of local com- } \\
\text { munities higher than actual importance; } \\
\text { implementation and increased probability } \\
\text { of success led to a convergence }\end{array}$ \\
\hline $\begin{array}{l}\text { Public Par- } \\
\text { ticipation } \\
\text { (Interaction) }\end{array}$ & $\begin{array}{l}\text { First, only pseudo participation with the } \\
\text { aim to market the project, after intense } \\
\text { conflicts also human resource- and social } \\
\text { value-based participation with the latter } \\
\text { putting the project at high risk } \\
\text { Trade-off between exchange of knowl- } \\
\text { edge/consideration of needs and ability to } \\
\text { act (e.g., cf. referendum) }\end{array}$ & $\begin{array}{l}\text { Integrated approach including authentic } \\
\text { participation and supporting marketing } \\
\text { activities (pseudo), additionally human } \\
\text { resource-based participation during plan- } \\
\text { ning and implementation to improve the } \\
\text { outcome } \\
\text { No trade-off with the ability to act as } \\
\text { mostly fact-based and well-framed partici- } \\
\text { pation tools }\end{array}$ \\
\hline $\begin{array}{l}\text { Conflict } \\
\text { Intensity } \\
\text { (Outcome) }\end{array}$ & $\begin{array}{l}\text { Conflict climax with }>100 \text { injured and } \\
\text { change of government after } 58 \text { years; } \\
\text { today less intense but still ongoing with } \\
\text { high number of opponents and divide in } \\
\text { society }\end{array}$ & $\begin{array}{l}\text { Compared to previous runway projects } \\
(1970 / 1980) \text { low conflict intensity with } \\
\text { focus on the topic and not on politics, for } \\
\text { instance, steadily decreasing number of } \\
\text { opponents }\end{array}$ \\
\hline
\end{tabular}

secondary stakeholders such as local communities. To summarize, these findings emphasize the influence of strategy on managerial perception, and thus, stakeholder analysis and interaction. They also highlight the importance of a more specific and context-related view on PSM, especially regarding stakeholder interaction. Finally, they prove that the different components are interlinked-a fact ignored in existing linear models (cf. Sect. 2.1).

Fig. 2 depicts the dynamic PSM model that results from the findings summarized in the previous paragraph. The components and their relations are based on the case analyses and the presented concepts. In the center of the model are the two main activities, analysis and interaction. Stakeholder salience helps examine the analysis component, while public participation gives substantiation to interaction. In line with other PSM models, we assumed that interaction depends on analysis (Cleland 1986; Eskerod and Jepsen 2013; Karlsen 2002; Suttrfield et al. 2006). However, the cases also revealed that analysis depends on interaction, as information exchange improves decision-making, for instance. On the left is the influencing factor. Nonmarket strategy acts as the underlying concept, but there are related characteristics, such as an organization's structure, resources, or culture-its nonmarket assets. They act as an enabler for analysis and interaction. As mentioned, strategies such as public CPA, private CPA, or politicized CSR influence the analysis through their impact on managers' perception of important stakeholders (cf. Buysse and Verbeke 2003; Henriques and Sadorsky 1999). Finally, the outcome is on the right. We chose conflict intensity, as this is expected to have significant consequences with regard to 
timely project termination or the reputation of the project partners involved (see introduction). Our case studies confirmed that this performance dimension is indeed critical as well as subject to a well-reflected project steering strategy or, in other words, PSM.

\section{Contributions, Limitations, and Future Research}

Owing to diverse cases such as the Keystone XL Pipeline, calls for the democratization of business processes are becoming louder, emphasizing the need for project stakeholder management (PSM) focusing on civic stakeholders (e.g., Crane et al. 2004; El-Gohary et al. 2006; Invernizzi et al. 2017; Rothfuß et al. 2012). Our research contributes to the literature at this intersection in several ways. As an overarching finding, it demonstrates empirically that successful PSM is also an outcome of private-oriented nonmarket strategies. Project organizations need strategies that shape perceptions and support interaction through the allocation of resources, clear responsibilities, the right incentives, and flexible organizational structures. However, nonmarket strategies should be inclusive and not target one player alone. Returning to the Keystone XL Pipeline example, it becomes evident that a pure focus on political players and the overall public is insufficient, as indigenous communities can mobilize powerful supporters, including environmental agencies and famous actors (BBC 2017). Our findings also confirmed that the role of managers is crucial, as they need to be aware of what influences their analyses and interactions. The dynamic PSM model (cf. Fig. 2) illustrates these strategic capabilities and interdependencies-facts that most existing models ignore despite their high relevance in the world of practitioners. Finally, our study revealed that it is possible to balance knowledge exchange, consideration of needs, and the ability to act when applying public participation tools. Striking this balance improves analyses and generates buy-in from civic actors, creating a self-enforcing cycle. Choosing the best-fitting instruments at the right time while steering expectations and clarifying the issues are important prerequisites. The negligence or wrong use of such tools can lead to massive financial and reputational losses, as the comparison between TransCanada's stock price and the project's key events (cf. CBC News 2017; Morningstar 2019) as well as the two studied cases clearly show.

As a by-product, this study also advanced the applied theoretical concepts. It enriched nonmarket strategy research by offering a practical example of the coupling of corporate political activity and corporate social responsibility (cf. Mellahi et al. 2016). Further, it added a data point for use in ongoing discussions regarding their impact on performance (cf. Wrona and Sinzig 2018). Second, this study provided empirical evidence that strategies affect the salience of not only primary, but also secondary stakeholders (Mitchell et al. 1997). Finally, it investigated public participation in a corporate-political context; the results demonstrated that it could support decision-making and implementation.

Despite its many contributions, this study has limitations. Its findings are contingent on the situations examined. While the results may not be universally generalizable, they nonetheless enable a more comprehensive view and support theory 
development. Additionally, the number of cases studied herein is limited, due to difficulties in finding comparable setups that offer broad access to data. The inclusion of further cases - especially from other countries-could enrich these findings. Further, our study focuses on nonmarket strategy; it ignores additional influences such as managerial personality, national culture, or the general political climate. However, we expect these to complement, rather than counter, our overall findings.

Future PSM research can advance our findings on two levels. First, scholars could use the model as guidance in refining our understanding of the linkages between PSM and the three theoretical approaches we selected for this study, or make use of other concepts that help connect the project management and the strategic management disciplines and contribute to productive theory building (Whetten 1989). Furthermore, it is essential to study the interplay between the company and the project organization, especially with regard to the chosen strategy and its implications for PSM. For instance, Fraport's initial public offering in 2001 dramatically changed and professionalized the company, leading to a different strategic approach. In addition, the model itself requires refinement via additional input factors, different forms of interaction, and measurable success factors. For the latter, it is possible to build on the six performance indicators identified for public participation in China (cf. Xie et al. 2017).

Second, the research results need to be accessible to practitioners, with an understandable narrative to ensure relevance and impact (Tong and Thomson 2015, p. 155). Propositions should be mirrored among practitioners, as public participation is an applied discipline that benefits from such exposure (Miller 2017). Further, an examination of innovative instruments-such as design-thinking (Elsbach and Stigliani 2018) or community benefit agreements (Ofer and Smyrk 2019)—offers immense possibilities to address challenges such as the mobilization of stakeholders to form the project's political context (Dorobantu and Odziemkowska 2017; Mahmoud-Jouini et al. 2016). For instance, Joos (2019) evaluated if early design thinking workshops with civic and political stakeholders improve the political environment of an infrastructure project. The expectation was that, by framing the problem and agreeing on basic conditions, the workshops support communication and engagement with citizens, thus minimizing conflicts and public protests that impede peaceful and efficient interaction. It was also expected that the additional external information from the workshops lead to a better result itself, independently of aspects related to the political environment. The initial results were promising but certainly need substantiation through more rigorous case study research.

Funding Open Access funding provided by Projekt DEAL.

Open Access This article is licensed under a Creative Commons Attribution 4.0 International License, which permits use, sharing, adaptation, distribution and reproduction in any medium or format, as long as you give appropriate credit to the original author(s) and the source, provide a link to the Creative Commons licence, and indicate if changes were made. The images or other third party material in this article are included in the article's Creative Commons licence, unless indicated otherwise in a credit line to the material. If material is not included in the article's Creative Commons licence and your intended use is not permitted by statutory regulation or exceeds the permitted use, you will need to obtain permission directly from the copyright holder. To view a copy of this licence, visit http://creativecommons.org/licenses/by/4. $0 \%$. 


\section{References}

Aaltonen, Kirsi. 2011. Project stakeholder analysis as an environmental interpretation process. International Journal of Project Management 29:165-183.

Aaltonen, Kirsi, and Jaako Kujala. 2010. A project lifecycle perspective on stakeholder influence strategies in global projects. Scandinavian Journal of Management 26:381-397.

Aaltonen, Kirsi, Jaakko Kujala, Laura Havela, and G. Savage. 2015. Stakeholder dynamics during the project front-end: the case of nuclear waste repository projects. Project Management Journal 46:15-41.

Achterkamp, Marjolein C., and Janita F.J. Vos. 2008. Investigating the use of the stakeholder notion in project management literature: a meta-analysis. International Journal of Project Management 26:749-757.

Aladpoosh, Hamid, Awaluddin Mohd Shaharoun, and Muhamad Zameri Mat Saman. 2012. Critical features for project stakeholder management: A systematic literature review. International Journal of Applied Systemic Studies 43:150-166.

Alcántara, Sophia, Nicolas Bach, Rainer Kuhn, and Peter Ullrich. 2016. Demokratietheorie und Partizipationspraxis (Democracy Theory and Participation Practice). Wiesbaden: Springer VS.

Amit, Raphael, and Paul J.H. Schoemaker. 1993. Strategic assets and organizational rent. Strategic Management Journal 14:33-46.

Arnstein, Sherry R. 1969. A ladder of citizen participation. Journal of the American Institute of Planners 35:216-224.

Bach, David. 2015. Nonmarket strategy: a politics and public policy approach. In The Routledge companion to nonmarket strategy, ed. Thomas C. Lawton, Tazeeb S. Rajwani, 66-82. Abingdon: Taylor \& Francis Group.

Bach, David David B.Allen. 2010. What every CEO needs to know about nonmarket strategy. MIT Sloan Management Review 51:41-48.

Badr, Touzi, Charif Mabrouki, and Abdelmajid Farchi. 2016. Competitive and sustainable road transport system: Stakeholder's analysis. International Journal of Advanced Information Science and Technology 5:1-15.

Barney, Jay B. 1991. Firm resources and sustained competitive advantage. Journal of Management 17:99-120.

Baron, David P. 1995. Integrated strategy: market and nonmarket components. California Management Review 37:47-66.

BBC. 2017. Dakota pipeline: what's behind the controversy? https://www.bbc.com/news/world-uscanada-37863955. Accessed 16 Aug 2019.

Bonardi, Jean-Philippe. 2011. Corporate political resources and the resource-based view of the firm. Strategic Organization 9:247-255.

Bonardi, Jean-Philippe, and Rick Vanden Bergh. 2015. Integrated market and non-market strategy: political knowledge and the resource-based view of the firm. In The Routledge companion to nonmarket strategy, ed. Thomas C. Lawton, Tazeeb S. Rajwani, 12-28. Abingdon: Taylor \& Francis Group.

Brabham, Daren C. 2009. Crowdsourcing the public participation process for planning projects. Planning Theory 8:242-262.

Brettschneider, Frank, and Wolfgang Schuster. 2013. Stuttgart 21: Ein Großprojekt zwischen Protest und Akzeptanz (Stuttgart 21: A megaproject between protest and acceptance). Wiesbaden: Springer.

Burby, Raymond J. 2003. Making plans that matter: citizen involvement and government action. Journal of the American Planning Association 69:33-49.

Burgelman, Robert A. 1983. A model of the interaction of strategic behavior, corporate context, and the concept of strategy. Academy of Management Review 8:61-70.

Buysse, Kristel, and Alain Verbeke. 2003. Proactive environmental strategies: a stakeholder management perspective. Strategic Management Journal 24:453-470.

Campos, Nauro F., and Frencesco Giovannoni. 2017. Political institutions, lobbying and corruption. Journal of Institutional Economics 13:917-939.

CBC News. 2017. A chronological history of controversial Keystone XL pipeline project. https://www. cbc.ca/news/politics/keystone-xl-pipeline-timeline-1.3950156. Accessed 16 Aug 2019.

CBS News. 2016. Keystone XL rejection leads TransCanada to sue Obama administration. http://www. cbc.ca/news/canada/calgary/transcanada-lawsuit-keystone-xl-pipeline-1.3392446. Accessed 30 May 2018 . 
Chandler, Alfred D. 1962. Strategy and structure: chapters in the history of the American industrial enterprise. Cambridge: MIT Press.

Cleland, David I. 1986. Project stakeholder management. Project Management Journal 17:36-44.

Crane, Andrew, Jeremy Moon, and Dirm Matten. 2004. Stakeholders as citizens? Rethinking rights, participation, and democracy. Journal of Business Ethics 53:107-122.

Dahan, Nicolas M. 2005. A contribution to the conceptualization of political resources utilized in corporate political action. Journal of Public Affairs 5:43-54.

Derakhshan, Roya, Rodney Turner, and Mauro Mancini. 2019a. Project governance and stakeholders: a literature review. International Journal of Project Management 37:98-116.

Derakshshan, Roya, Mauro Mancini, and Rodney Turner. 2019b. Community's evaluation of organizational legitimacy: formation and reconsideration. International Journal of Project Management 37:73-86.

Dorobantu, Sinziana, and Kate Odziemkowska. 2017. Valuing stakeholder governance: property rights, community mobilization, and firm value. Strategic Management Journal 38:2682-2703.

Dorobantu, Sinziana, Assem Kaul, and Bennet A. Zelner. 2017. Nonmarket strategy research through the lens of new institutional economics: An integrative review and future directions. Strategic Management Journal 38:114-140.

Dubois, Anna, and Lars-Erik Gadde. 2002. Systematic combining: an abductive approach to case research. Journal of Business Research 55:553-560.

Eisenhardt, Kathleen M. 1989. Building theories from case study research. Academy of Management Review 14:532-550.

Eisenhardt, Kathleen M. 1991. Better stories and better constructs: the case for rigor and comparative logic. Academy of Management Review 16:620-627.

Eisenhardt, Kathleen M., and Melissa E. Graebner. 2007. Theory building from cases: opportunities and challenges. Academy of Management Journal 50:25-32.

Eisenhardt, Kathleen M., E. Melissa, and Scott Sonensheim. 2016. Grand challenges and inductive methods: rigor without rigor mortis. Academy of Management Journal 59:1113-1123.

El-Gohary, Nora M., Hesham Osman, and Tamer E. El-Diraby. 2006. Stakeholder management for public private partnerships. International Journal of Project Management 24:595-604.

Elsbach, Kimberly D., and Illeana Stigliani. 2018. Design thinking and organizational culture: a review and framework for future research. Journal of Management 44:2274-2306.

Eskerod, Pernille, and Anne Live Vaagaasar. 2014. Stakeholder management strategies and practices during a project course. Project Management Journal 45(5):71-85.

Eskerod, Pernille, and Anna Lund Jepsen. 2013. Project stakeholder management. Surrey: Gower.

Eskerod, Pernille, Martina Huemann, and Clausia Ringhofer. 2015a. Stakeholder inclusiveness: Enriching project management with general stakeholder theory. Project Management Journal 46:42-53.

Eskerod, Pernille, Martina Huemann, and Grant Savage. 2015b. Project stakeholder management—Past and present. Project Management Journal 46:6-14.

Flyvbjerg, Bent. 2016. Five misunderstandings about case-study research. Qualitative Inquiry 12:219-245.

Flyvbjerg, Bent, and J. Rodney Turner. 2017. Do classics exist in megaproject management? International Journal of Project Management 36:334-341.

Flyvbjerg, Bent, Nils Bruzelius, and Werner Rothengatter. 2003. Megaprojects and risk: an anatomy of ambition. Cambridge: Cambridge University Press.

Fraport. 2014. Fluglärm Reduzieren (Reducing Aircraft Noise). Frankfurt/Main: Fraport.

Freeman, R. Edward. 1984. Strategic management: a stakeholder approach. Boston: Pitman Publishing.

Freeman, R. Edward, and Daniel R. Gilbert. 1988. Corporate strategy and the search for ethics. Englewood Cliffs: Prentice-Hall.

Funk, Russel J., and Daniel Hirschman. 2017. Beyond nonmarket strategy: market actions as corporate political activity. Academy of Management Review 42:32-52.

Gephart, Robert P. 2004. Qualitative research and the Academy of Management Journal. Academy of Management Journal 47:454-462.

Gioia, Denny A. 2004. A renaissance self: Prompting personal and professional revitalization. In Renewing research practice, ed. Ralph E. Stablein, Peter J. Frost, 97-114. Stanford: Stanford University Press.

Hall, David J., and Maurice A. Saias. 1980. Strategy follows structure! Strategic Management Journal $1: 149-163$.

Henriques, Irene, and Perry Sadorsky. 1999. The relationship between environmental commitment and managerial perceptions of stakeholder importance. Academy of Management Journal 42:87-99.

Herian, Mitchel, Joseph A. Hamm, Alan Tomkins, and Lisa M. Pytlik Zillig. 2012. Public participation, procedural fairness, and evaluations of local governance: The moderating role of uncertainty. Journal of Public Administration Research and Theory 22:815-840. 
Hiatt, Shon R., Jake B. Grandy, and Brandon H. Lee. 2015. Organizational responses to public and private politics: an analysis of climate change activists and U.S. oil and gas firms. Organization Science 26:1769-1786.

Hillman, Amy J., and Michael Hitt. 1999. Corporate political strategy formulation: a model of approach, participation and strategic decisions. Academy of Management Review 24:825-842.

Hillman, Amy J., Gerald D. Keim, and Douglas Schuler. 2004. Corporate political activity: a review and research agenda. Journal of Management 30:837-857.

Holburn, Guy, Margaret Loudermilk, and Dennis McConaghy. 2016. TransCanada's Keystone XL pipeline: Unfinished business. Harvard Business (HBR) case study.

Invernizzi, Diletta C., Gorgio Locatelli, and Naomi J. Brookes. 2017. Managing social challenges in the nuclear decommissioning industry: A responsible approach towards better performance. International Journal of Project Management 35:1350-1364.

Jones, Thomas M. 1995. Instrumental stakeholder theory: a synthesis of ethics and economics. Academy of Management Review 20:404-437.

Jones, Thomas M., Will Felps, and Gregory A. Bigley. 2007. Ethical theory and stakeholder-related decisions: the role of stakeholder culture. Academy of Management Review 32:137-155.

Joos, Hannah C. 2018. Influences on managerial perceptions of stakeholder salience: two decades of research in review. Management Review Quarterly 69:1-35.

Joos, Hannah C. 2019. Design thinking: A suitable instrument for citizen engagement within private CPA? Working Paper. Berlin: TU.

Jun, Kyu-Nahm, and Thomas Bryer. 2017. Facilitating public participation in local governments in hard times. American Review of Public Administration 47:840-856.

Kanter, Rosabeth M. 1977. Men and women of the corporation. New York: Basic Books.

Karlsen, Jan T. 2002. Project stakeholder management. Engineering Management Journal 14:19-24.

Killen, Catherine P., Kam Jugdev, Nathalie Drouin, and Yvan Petit. 2012. Advancing project and portfolio management research: applying strategic management theories. International Journal of Project Management 30:525-538.

Kirsch, Werner. 1990. Unternehmenspolitik und Strategische Unternehmensführung (Corporate Policy and Strategic Business Management), 1st edn., Munich: Barbara Kirsch.

Kirsch, Werner. 1997. Wegweiser zur Konstruktion einer evolutionären Theorie der strategischen Führung: Kapitel eines Theorieprojektes (Guide to the Construction of an Evolutionary Theory of Strategic Leadership: Chapter of a Theoretical Project). Munich: Barbara Kirsch.

Kirsch, Werner, Werner-Michael Esser, and Eduard Gabele. 1978. Reorganisation: Theoretische Perspektiven des geplanten organisatorischen Wandels (Reorganization: Theoretical Perspectives of the Planned Organizational Change). Munich: Planungs- und Organisationswissenschaftliche Schriften.

Kirsch, Werner, Wolfgang Scholl, and Günther Paul. 1984. Mitbestimmung in der Unternehmenspraxis: Eine empirische Bestandsaufnahme (Co-Determination in Business Practice: An Empirical Review). Munich: Planungs- und Organisationswissenschaftliche Schriften.

Zu Knyphausen-Aufseß, Dodo, and Lars Schweizer. 2011. Industry evolution and the interplay between extrinsic and intrinsic motivation. Software and genomics from a Habermasian perspective. Managementforschung 21:215-247.

Koskela, Lauri, and Gregory A. Howell. 2002. The underlying theory of project management is obsolete. Paper presented at PMI ${ }^{\circledR}$ Research Conference 2002: Frontiers of Project Management Research and Applications, Seattle. Newtown Square: Project Management Institute.

Kuchler, Magdalena. 2017. Stakeholding as sorting of actors into categories: implications for civil society participation in the CDM. International Environmental Agreements: Politics, Law and Economics 17:191-208.

Lamberg, Juha-Antti, Mika Skippari, Jari Eloranta, and Saku Makinen. 2004. The evolution of corporate political action: a framework for processual analysis. Business \& Society 43:335-365.

Langley, Ann. 1999. Strategies for theorizing from process data. Academy of Management Review 24:691-710.

Langley, Ann, and Abdallah Charazad. 2011. Templates and turns in qualitative studies of strategy and management. In Building methodological bridges, ed. Donald D. Bergh, David J. Ketchen, 201-235. Bingley: Emerald Group.

Laplume, André O., Karan Sonpar, and Reginald A. Litz. 2008. Stakeholder theory: reviewing a theory that moves us. Journal of Management 34(6):1152-1189.

Lawton, Thomas C., and Tazeeb S. Rajwani. 2015. The Routledge companion to non-market strategy. Abington: Routledge. 
Lawton, Thomas C., Steven McGuire, and Tazeeb S. Rajwani. 2013. Corporate political activity: a literature review and research agenda. International Journal of Management Reviews 15:86-105.

Littau, Paul, Nirmala J. Jujagiri, and Gerald Adlbrecht. 2010. 25 years of stakeholder theory in project management literature (1984-2009). Project Management Journal 41:17-29.

Lock, Irina, and Peter Seele. 2017. Politicized CSR: how corporate political activity (mis-)uses political CSR. Journal of Public Affairs 18:1-9.

Ma, Hanyang, S.X. Zeng, Han Lin, Hongquan Chen, and Jonathan J. Shi. 2017. The societal governance of megaproject social responsibility. International Journal of Project Management 35:1365-1377.

Macher, Jeffrey T., and John W. Mayo. 2015. Influencing public policymaking: Firm-, industry-, and country-level determinants. Strategic Management Journal 36:2021-2038.

Mahmoud-Jouini, Sihem B., Christophe Midler, and Philippe Silberzahn. 2016. Contributions of design thinking to project management in an innovation context. Project Management Journal 47:144-156.

Mellahi, Kamel, Jędrzej George Frynas, Pei Sun, and Donald Siegel. 2016. A review of the nonmarket strategy literature: toward a multi-theoretical integration. Journal of Management 42:143-173.

Miles, Matthew B., and A. Michael Huberman. 1994. Qualitative data analysis: an expanded sourcebook, 2nd edn., Thousand Oaks: SAGE.

Miller, Danny. 2017. Disruptive texts: case narratives as research inspirations. Academy of Management Review 42:154-164.

Mintzberg, Henry. 1978. Patterns in strategy formation. Management Science 9:67-86.

Mitchell, Ronald K., Donna J. Wood, and Bradley Agle. 1997. Toward a theory of stakeholder identification and salience: Defining the principle of who and what really counts. Academy of Management Review 22:853-886.

Mok, Ka Yan, Geoffrey Q. Shen, and Jing Yang. 2015. Stakeholder management studies in mega construction projects: a review and future directions. International Journal of Project Management 33:446-457.

Morningstar. 2019. 10Y stock price TransCanada corp. http://quote.morningstar.ca/Quicktakes/Stock/s_ca. aspx?t=TRP. Accessed 9 Feb 2019.

Musawir, Ata ul, Carlos E. M. Serra, Zwikael Ofer, and Ali Imran. 2017. Project governance, benefit management, and project success: Towards a framework for supporting organizational strategy implementation. International Journal of Project Management 35:1658-1672.

Nguyen, Tuan S., Sherif Mohamed, and Kriengsak Panuwatpanich. 2018. Stakeholder management in complex project: review of contemporary literature. Journal of Engineering, Project, and Production Management 8:75-89.

Novy, Johannes, and Deike Peters. 2012. Railway station mega-projects and the re-making of inner Ccties in Europe. Built Environment 38:128-145.

Ofer, Zwikael, and John R. Smyrk. 2019. Project management. A benefit realisation approach. London: Springer.

Okhuysen, Gerardo A., and Jean-Philippe Bonardi. 2011. Editors' comments: the challenges of building theory by combining lenses. Academy of Management Review 36:6-11.

Oliver, Christine, and Ingo Holzinger. 2008. The effectiveness of strategic political management: a dynamic capabilities framework. Academy of Management Review 33:496-520.

Oppong, Goodenough D., Albert P.C. Chan, and Ayirebi Dansoh. 2017. A review of stakeholder management performance attributes in construction projects. International Journal of Project Management 35:1037-1051.

Orueta, Fernando D., and Susan S. Fainstein. 2008. The new mega-projects: genesis and impacts. International Journal of Urban and Regional Research 32:759-767.

Packendorff, Johann. 1995. Inquiring into the temporary organization: new directions for project management research. Scandinavian Journal of Management 11:319-333.

Papke-Shields, Karen E., and Kathleen M. Boyer-Wright. 2017. Strategic planning characteristics applied to project management. International JournaL of Project Management 35:169-179.

Parent, Milena M., and Davod L. Deephouse. 2007. A case study of stakeholder identification and prioritization by managers. Journal of Business Ethics 75:1-23.

Parmar, Bidhan L., R. Edward Freeman, Jeffrey S. Harrison, Andrew C. Wicks, Lauren Purnell, and Simone de Colle. 2010. Stakeholder theory: the state of the art. Academy of Management Annal 4(1):403-445.

Patzer, Moritz, Christian Voegtlin, and Andreas G. Scherer. 2018. The normative justification of integrative stakeholder engagement: a Habermasian view on responsible leadership. Business Ethics Quarterly 28:325-354. 
Peters, Deike, and Johannes Novy. 2012. Train station area development mega-projects in Europe: towards a typology. Built Environment 38:12-30.

Pfeffer, Jeffrey. 1987. Bringing the environment back in: The social context of business strategy. In The competitive challenge: Strategies for industrial innovation and renewal, ed. David J. Teece, 119-135. Cambridge MA: Ballinger.

Phillips, Robert, R. Edward Freeman, and Andrew C. Wicks. 2003. What stakeholder theory is not. Business Ethics Quarterly 13:479-502.

Pryke, Stephen, Sulafa Badi, and Lena Elisabeth Bygballe. 2017. Editorial for the special issue on social networks in construction. Construction Management and Economics 35:445-454.

Ridder, Hans-Gerd. 2017. The theory contribution of case study research designs. Business Research 10:281-305.

Rothfuß, Rainer, Camilla Perrone, and Rogerio Mororó. 2012. Direct democracy in decision making for mega-projects: a new culture of "governance in partnership"? Journal of Settlements and Spatial Planning 3:63-75.

Savage, Grant T., Timothy W. Nix, Carlton J. Whitehead, and John D. Blair. 1991. Strategies for assessing and managing organizational stakeholders. Academy of Management Perspectives 5(2):61-75.

De Schepper, Steven, Michael Dooms, and Elvira Haezendonck. 2014. Stakeholder dynamics and responsibilities in public-private partnerships: a mixed experience. International Journal of Project Management 32:1210-1222.

Scherer, Andreas G., and Guido Palazzo. 2007. Toward a political conception of corporate responsibility: business and society seen from a Habermasian perspective. Academy of Management Review 32:1096-1120.

Scherer, Andreas G., and Guido Palazzo. 2011. The new political role of business in a globalized world: a review of a new perspective on CSR and its implications for the firm, governance, and democracy. Journal of Management Studies 48:899-931.

Scherer, Andreas G., and Moritz Patzer. 2011. Where is the theory in stakeholder theory? A meta-analysis of the pluralism in stakeholder theory. In Stakeholder theory. Impact and prospects, ed. Robert A. Phillips, 140-162. Cheltenham Glos: Edward Elgar Publishing.

Schmidt-Thomé, Kaisa, and Raine Mäntysalo. 2014. Interplay of power and learning in planning processes: a dynamic view. Planning Theory 13:115-135.

Schuler, Douglas A. 1996. Corporate political strategy and foreign competition: The case of the steel industry. Academy of Management Journal 39:720-737.

Seltzer, Ethan, and Dillon Mahmoudi. 2013. Citizen participation, open innovation, and crowdsourcing: Challenges and opportunities for planning. Journal of Planning Literature 28:3-18.

Siggelkow, Nicolai. 2007. Persuasion with case studies. Academy of Management Journal 50:20-24.

Söderlund, Jonas. 2004. Building theories of project management: past research, questions for the future. International Journal of Project Management 22:183-191.

Stoney, Christopher, and Diana Winstanley. 2001. Stakeholding: confusion or utopia? Mapping the conceptual terrain. Journal of Management Studies 38:603-626.

Suchman, Mark C. 1995. Managing legitimacy: Strategic and institutional approaches. Academy of Management Review 20:571-610.

Suttrfield, J. Scott, Shawnta S. Friday-Stroud, and Sheryl L. Shivers-Blackwell. 2006. A sase study of project and stakeholder management failures: Lessons learned. Project Management Journal 37:26-36.

Swyngedouw, Erik. 2005. Governance innovation and the citizen: the Janus face of governance-beyondthe-state. Urban Studies 42:1991-2006.

Teo, Melissa M., and Martin Loosemore. 2017. Understanding community protest from a project management perspective: a relationship-based view. International Journal of Project Management 35:1444-1458.

Tong, Michael, and Craig Thomson. 2015. Developing a critical literature review for project management research. In Designs, methods and practices for research of project management, ed. Beverly Pasian, 153-172. Abington: Routledge.

Turkulainen, Virpi, Kirsi Aaltonen, and Päivi Lohikoski. 2015. Managing project stakeholder communication: the Qstock festival case. Project Management Journal 46(6):74-91.

Venkatraman, N., and C. Camillus John. 1984. Exploring the concept of "fit" in strategic management. Academy of Management Review 9:513-525.

Watkins, G.J., S.-U. Mueller, H. Meller, M.C. Ramirez, T. Serebrisky, and A. Georgoulias. 2017. Lessons from four decades of infrastructure project-related conflicts in Latin America and the Caribbean. Washington DC: Inter-American Development Bank. 
Weingart, Laurie R., Kristin J. Behfar, Corinne Bendersky, Gergana Todorova, and Karen A. Jehn. 2015. The directness and oppositional intensity of conflict expression. Academy of Management Review 40:235-262.

Whetten, David A. 1989. What constitutes a theoretical contribution? Academy of Management Review 14:490-495.

Wille, Joachim. 2019. Stuttgart 21 bringt Bahn in Schieflage (Stuttgart 21 Threatens DB's Business). Frankfurter Rundschau 2 January.

Wrona, Thomas, and Corinna Sinzig. 2018. Nonmarket strategy research: Systematic literature review and future directions. Journal of Business Economics 88:253-317.

Xie, Lin-Lin, Bo Xia, Yi Hu, Ming Shan, Le Yun, and Albert P.C. Chan. 2017. Public participation performance in public construction projects of south China: A case study of the Guangzhou games venues construction. International Journal of Project Management 35:1391-1401.

Yang, Rebecca J. 2014. An investigation of stakeholder analysis in urban development projects: Empirical or rationalistic perspectives. International Journal of Project Management 32:838-849.

Yin, Robert K. 1994. Case study research—design and methods, 2nd edn., Thousand Oaks: SAGE.

Publisher's Note Springer Nature remains neutral with regard to jurisdictional claims in published maps and institutional affiliations. 